\title{
不整脈の診断論理
}

渡部良夫*

不整脈の診断論理は, 特殊伝導系細胞の自動能による刺激生成, 活動電位発生に伴う興 舊伝導亡不応期といつたいくつかの電気生理学的特性をもとに組み立てられる. そうした 論理中, (1)P波の現われ方による洞調律の同定法, (2)PとQRS が同頻度で現われPR 時 間が一定なら単一の歩調取り機構を考え, (3)PとQRS の出現頻度が異なり, しかも各々 の周期が一定の場合は房室解離状態を, (4)心房と心室の頻度が異なり, 高頻度の方が一定, 低頻度の方が変動するときは, 前者からの伝導ブロックをそれぞれ疑うこと, (5)基本調律 が洞性のときに突然周期が短縮すれば期外収縮が，(6)基本調律よりも長い間隔で出る心拍 では補充収縮が示唆されること，(7)異所性心拍が連続出現するときは，その頻度により発 作性頻拍, 非発作性頻拍, 異所性調律を鑑別すること, (8)不応期の知識を用いた伝導障害 や心室内变行伝導の判定，(9)歩調取り細胞の復原周期，(10)不整脈解析におけるP波同定の 重要性, などの諸点を実例を用いて解説した。

(心電図12：No.2, 161 167, 1992)

\section{I .はじめに}

不整脈の診断論理は, (1)特殊伝導系の自動 性細胞は，他からの刺激で周期を乱されない かぎり，拡張期脱分極によってほぼ一定の周 期で刺激を生成できること，(2)心筋細胞は刺 激に応じて活動電位を生じ, これは興奮波と して周囲の細胞群に伝導されて行くこと,(3) いったん活動電位が生ずると細胞は不応期に 陥り，再分極が進んで興奮性が回復するまで 新たな刺激には応答しないこと，といったい

\begin{tabular}{|c|c|}
\hline Key Words & $\begin{array}{l}\text { - 不整脈 } \\
\text { - 心筋電気生理学 } \\
\text { ○電図 }\end{array}$ \\
\hline
\end{tabular}

* 藤田保健衛生大学総合医科学研究所心血管学研究部門 （テ470-11 豊明市沓掛町田楽が淮 1-98）
くつかの電気生理学的特性を基礎として組み 立てられるわけで, 本来極めて容易に理解で きるはずである。しかし，不整脈は心臓内の 異なる部位で, これらの特性の異常が種々の 形で組み合わさって起こるものであり,さら に心電図には，不整脈の発生に重要な役割を 果たす特殊伝導系の電気的活動は現われず, それを心房筋と心室筋の興奮のみから推測せ ざるを得ないために，実際の診断論理は複雑 多岐にわたる。ここでは，最初にそれらの一 部を叙述し，次いで少数の心電図につき，そ うした論理をいかに応用していくかを例示し てみよう。

\section{II. 主要な診断論理}

（1）調律異常の心電図診断の第一歩は洞性

The logic used in arrhythmia diagnosis Yoshio Watanabe 
心拍の同定にある. 安定した生理的条件の下 では，一定時間がたてば常に洞結節で刺激が 生成され，これが心房の興奮を支配するので， 異所性心房興奮は洞周期よりも短い間隔でな ければ現われ得ない。したがって，異なる波 形と周期を持つ種々の $\mathrm{P}$ 波がみられるときに は，最も長い間隔の後で現われ，しかも上方 から下方に向かう心房興奮を示唆する ( I , $\mathrm{II}, a \mathrm{~V}_{\mathrm{F}}$ の各誘導で陽性の) P 波が，洞性であ る確率が大である。

(2) P 波と QRS とが同じ頻度で現われて， PR 時間が一定であれば，心房と心室の同一 調律による支配が考えられ，その種類は心拍 数， $\mathrm{P}$ とRSの波形と時間関係などを参照 して決定される．たとえばP波の極性が II， III, ${ }_{\mathrm{a}} \mathrm{V}_{\mathrm{F}}$ で陰性ならば心房の逆行性興奮が示 唆され，PR 時間が正常よりも短かければ房 室接合部での刺激発生が考えられるといった 具合である。

(3) $\mathrm{P}$ と $\mathrm{QRS}$ の出現頻度が異なり, しかも それぞれの周期は一定にとどまる場合は，二 つの独立した歩調取り機構が心房と心室を別 個に支配する房室解離の状態があるとみてよ い. その際，心房の興奮頻度の方が高ければ, 第 3 度房室ブロックが最も有力となり，逆に 心室興奮頻度が高いときは異所性頻拍が示唆 される、いずれの場合にも，心室を支配する 刺激の発生部位推定には, QRS の波形が参考 になる。

（4）心房と心室の興奮頻度が異なるとき，よ り高い頻度で興奮している方が一定の周期を 保ち，低い頻度で興奮する側が周期の変動を 示す場合には，前者から後者への伝導ブロッ クを疑う。逆に，たとえば心房が比較的低い 一定の頻度で興奮しており，それよりも高い 頻度を示す心室の周期がときどき，さらに短 縮するようなときには，心室から心房への伝 導は途絶し，心房からの興奮伝導が房室接合 部の不応期の間隙を縫って心室捕捉を起こす ことが示唆される。

(5) 洞調律時に突然短い周期で現われる心
拍は，まずもって期外収縮と考えてよい。そ の刺激発生部位は，早期に出るのが $\mathrm{P}$ 波だけ であれば，心房または房室接合部，QRS のみ であれば房室接合部 (QRS 時間正常)または 心室 (QRS 時間延長) と考えられ， $\mathrm{P}$ も $\mathrm{QRS}$ も早期に出ていれば，両者の波形と時間関係 を参考にして決定する。

(6) 基本調律よりも長い間隔をおいて現わ れる心拍は，洞性刺激発生の遅延や伝導ブロ ックによる長い休止期に下位自動が現われる ための補充収縮であることが多い.

（7）異所性心拍が連続出現した場合, それが 洞頻脈の範囲を超えるような頻度で突然始ま れば，リエントリーなどの機序による発作性 頻拍が示唆される．始まりが緩徐な場合には， その頻度が異所性刺激生成部位の生理的自動 能の範囲内にあれば異所性調律を考え，その 範囲を超えて高ければ非発作性頻拍を疑う。

(8) 心筋組織は刺激による興奮後一定時間 不応期に陥り，その間に刺激が加えられても 興奮や伝導は行われない. 長い周期の後には 伝導系(特に Purkinje 細胞群)の不応期が延 長する傾向がある。こうした不応期の知識を 用いて，不顕伝導に伴う房室伝導障害，上室 性刺激の心室内変行伝導などの現象を診断す る.

（9）自動能を有する細胞群が他からの刺激 で興奮させられると，自動周期が更新され， その点から本来の周期に近い間隔の後に再び 刺激を作り出す，異所性 $\mathrm{P}$ 波から次の洞性 $\mathrm{P}$ 波までの時間が，洞周期に往復の洞房伝導時 間を加えた値になる洞結節の復原周期の現象 は，この代表例である。

(10) 以上のすべてを通じて, P波の同定が極 めて大切であることが知られる。したがって $\mathrm{P}$ 波がみられず，基線が細かな動摇を示す心 房細動では，心房興奮と心室興奮との時間関 係は不明となり，また計測できるものは心室 興奮周期 $(\mathrm{R}-\mathrm{R}$ 間隔)のみとなって，不整脈の 診断は困難になることが理解できよう。この 際には, 心房興奮の伝導によって生ずる QRS 
群が不規則に現われ, 心室頻度の一定化がむ しろ房室ブロックや下位自動の発生を疑わせ る.

いずれにしても，P-P 間隔， P-R 時間， $\mathrm{R}$ $-\mathrm{R}$ 間隔を厳密に計測し, その上でこれらの一 般原理を応用することによって，ほとんどの 調律異常は12誘導心電図で診断できる.

\section{III. 心電図診断の実例}

図 1 でまず第II誘導をみると, P波は周期 1.20 秒程度で規則正しく出現し, QRS は周期 約 2 秒でこれも規則正しく現われている。こ うした場合には, 心房と心室がそれぞれ別個 の歩調取り(あるいは自動性細胞群)によって 支配されていると考え, 頻度のより高い心房 の調律が心室興奮を支配できないのは伝導障 害があるためとみて, 第 3 度房室ブロックが
診断される. 他の誘導でも全く同様の所見が 得られる。ここで $\mathrm{QRS}$ 幅が正常なことは下 位自動中枢が His 束分岐部より上流にある ことを示唆し,伝導途絶部は(最終的にはカ.テ ーテル電極を用いた臨床電気生理学的検査を 必要とするが)おそらく房室結節内であろう。

しかし，それでは第 3 度房室ブロックの診 断にはいつもこのように簡単な論理で足りる かといえば，必ずしもそうではない．たとえ ば図 2 では, 心室群は周期 1.52 秒で規則正し く現われているが，それより高い頻度で出て いる $\mathrm{P}$ 波の周期は不規則である。そのうち第 $\mathrm{II}$ 誘導の後半とか $\mathrm{a}_{\mathrm{F}}$ 誘導の中央部のように 0.86 秒の P-P 間隔が繰り返されるところは, おそらく洞調律を表わすものと思われる。こ れに対して $\mathrm{V}_{\mathrm{R}} \mathrm{V}_{\mathrm{R}}$ 導では, 第 1 拍の $\mathrm{T}$ 波の後 で 0.46 秒という短い $\mathrm{P}-\mathrm{P}$ 間隔がみられ，心房

2

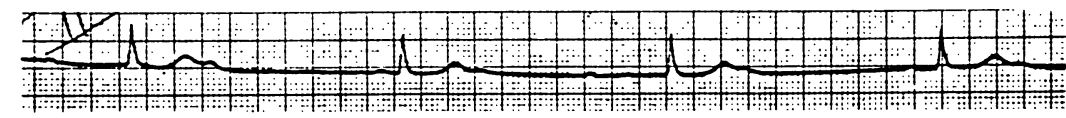

3
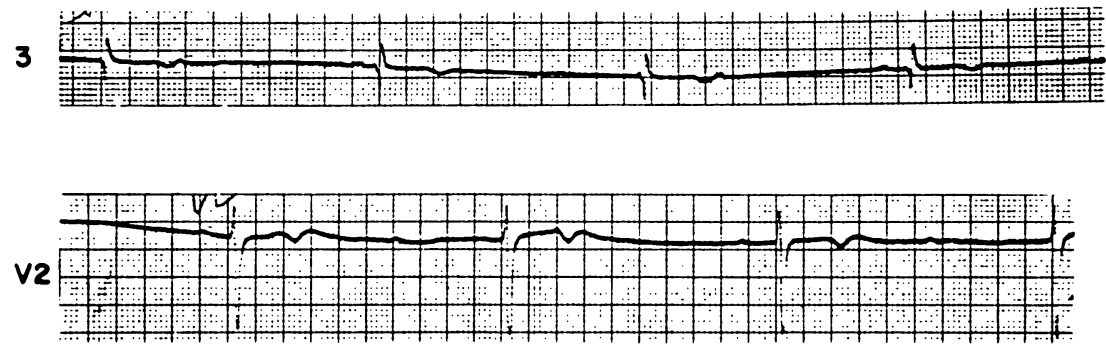

図 1 単純な形の第 3 度房室ブロック

II

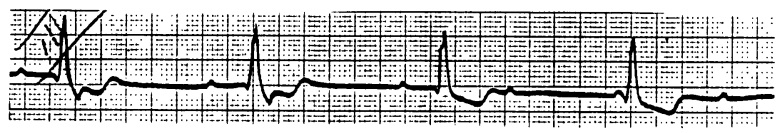

aVR

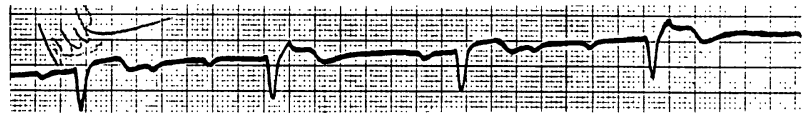

aVF

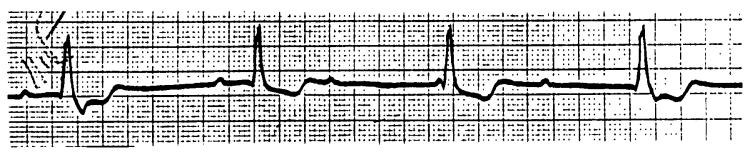

図 2 心房興奋波は心室に伝導されず第 3 度ブロックの状態を示すが, 心 室から心房への逆伝前はときどき可能な房室一方向伝導の一症例 
上部から下部に向かう脱分極波を示す陰性の $\mathrm{P}$ 波のみが早期に現われることから，心房期 外収縮が診断される.より高い頻度で出るこ れらの $\mathrm{P}$ 波が心室周期に影響を与えない点か らは，ここでも高度房室ブロックの存在が示 唆されよう。 QRS 幅が0.13秒あるのは His 束分岐部より下流での刺激生成を推測させ， 伝導途絶が房室接合部より下流で生じている 確率が高い。

一方, QRS の終了直後に第 II誘導と $\mathrm{V}_{\mathrm{F}}$ で 陰性， $\mathrm{a}_{\mathrm{R}}$ で陽性の $\mathrm{P}$ 波がみられるのは心房 の逆行性興奮を表わし，心室から心房への一 方向性伝導の存在を示す。この逆行性 $\mathrm{P}$ 波か ら次の洞性 $\mathrm{P}$ までの間隔が洞周期より約 200 msec 長いのは，異所性心房興奮波が洞結節 の自動周期を更新したための復原周期の現象 による.また，下位自動による QRS 群が逆行 性 $\mathrm{P}$ 波を伴わない場合には，その QRS 群の 前 $280 \mathrm{msec}$ 以内に $\mathrm{P}$ 波がみられることから， 上室性興奮波の不顕伝導 (concealed conduction)によって生じた房室接合部の不応期が, 心室興奮波の心房への逆伝導を妨げているこ とが理解できよう。

次に図 3 においては，まず上段の第II，第 III誘導同時記録で，陽性の $\mathrm{P}$ 波が比較的長い $\mathrm{P}-\mathrm{P}$ 間隔の後で出現する場合に，洞調律が示 唆され，その周期は約 0.90 秒である.すると， 先行する $\mathrm{P}$ 波を持たずに $\mathrm{QRS}$ 群のみが早期
に現われる第 3 拍や第15拍は，その幅が広く， また ST-T の異常を伴うことから，心室期外 収縮であると考えられ，それに続いてこれと 同じ波形の QRS が毎分150以上の高頻度で 連続出現するところは, 発作性心室頻拍の発 生を示す。この誘導では 2 回のそうした頻拍 発作がみられ，いずれも10拍続いた後に停止 しているので, 非持続性心室頻拍の診断が下 される，そして，第 2 回目の発作の部分では， 心室がより高い頻度で興奮しているのに心房 が低い頻度で洞調律を保っていることは，心 室から心房への伝導の障害を意味する一方， 洞性興奮波が心室からの逆行性不顕伝導によ る房室伝導系の不応期に妨げられて心室に到 達できず，房室解離の状態をきたしたことが 理解されよう。

これに対して，第 1 回の発作に際しては, 高い頻度の心室興奮が(最後の 2 心拍を除き) やはり規則正しく現われている一方，陰性 $\mathrm{P}$ 波で表わされる低い頻度の心房興奮の出現は 不規則である。このことは逆行性伝導ブロッ クを示唆し, 事実, 陰性 $\mathrm{P}$ 波の現われ方は最 初の 5 個までは $2 ： 1$ 伝導を, 最後の部分は 1：1伝導を示す。このように伝導比率が 2：1から 1：1に変化したのは，心室頻拍 の周期が最後にやや延長したため, 前の心拍 の逆伝導による房室伝導系の不応期が終了し た時点で心室からの興奮波が到達したためと
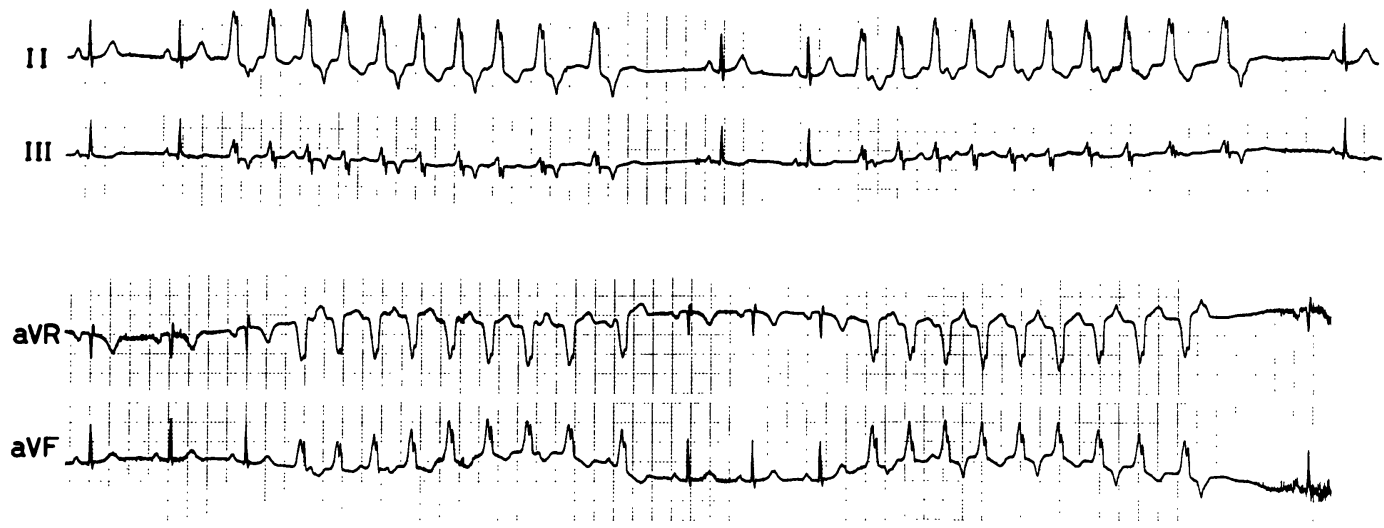

図 3ととには 2：1ブロックを伴う心房への逆伝導を，またときには房室解離を示す非持続性心室頻拍 
考えられる。ここでも，逆伝導による $\mathrm{P}$ 波か ら次の洞性 $\mathrm{P}$ 波までの間隔は洞周期よりやや 長く, 復原周期の現象を示す。 下段の $\mathrm{a}_{\mathrm{R}}$, ${ }_{\mathrm{a}} \mathrm{V}_{\mathrm{F}}$ 誘導でみられる 2 回の発作では, 前半が房 室解離，後半が主として $2 ： 1$ の逆伝導を示 している.

さて，図 4 に掲げた心電図では，周期 0.86 秒の正常洞調律の間にときどき早期に出現す る QRS がみられ，その波形は異常で幅広く， 心室起源を疑わせる。しかしょくみれば，そ れらの QRS 群の直前には洞周期よりも短い 間隔で出現した $\mathrm{P}$ 波が認められ，両者の因果 関係を示唆する.そこでまず考えられるのは, 心房期外収縮の興奮波が心室内伝導系の不応 期に遭遇して，変行伝導をきたした可能性で あろう。しかし，そうした場合には, PR(房室 (伝導)時間は正常の洞性心拍のそれよりも幾 分延長することが多いのに，ここでは逆に短 い.この所見を最もよく説明する方法は，お そらく心房期外収縮の興奮波が房室間の副伝 導路(Kent 束)を優先的に通って心室に達し, 早期興奮を生じたとみるものである。そして, こうした解釈が正しかったことは，本症例で この数週間後に得られた心電図において，心 房細動の発生に伴い, 著明なデル夕波を有す
る異常 $\mathrm{QRS}$ 群が不規則・高頻度に現われて 心室の早期興奮を示したことで裏書きされた。

以上のいくつかの実例からも不整脈の心電 図診断では，常に $\mathrm{P}-\mathrm{P}, \mathrm{PR}$ および $\mathrm{R}-\mathrm{R}$ の三 つの時間間隔を計測すべきであり，P波の同 定がいかに重要な役割を演ずるかが理解され る。したがって，次の図 5 にみるように明ら かな $\mathrm{P}$ 波がなく，基線が細かな動摇を示す心 房細動の症例では, QRS 群と心房興奮の因果 関係の証明がむつかしく，不整脈の診断は困 難となる。本例における $\mathrm{R}-\mathrm{R}$ 間隔は明らかに 不規則であるが，すべての間隔を計測すると 1.60 秒という值が 6 回繰り返して認められる ことが注目される。しかも，これが R-R 間隔 中で最も長い点が重要であり，これらの心拍 が房室接合部の自動能による補充収縮を表わ すことが強く示唆されよう。なお，この場合， そうした房室接合部の自動能が表面に現われ るためには，その細胞群の拡張期脱分極が心 房からの興奮波により中断されずに持続する ことが必要であり，ある程度の房室伝導障害 が存在しなければならない.

最後に, 図6の心電図をみると，基線の動 摇と $\mathrm{P}$ 波の欠如がやはり心房細動を示してい るが，ここでは正常幅の QRS にまざって幅

\section{$7 / 12 / 88$}
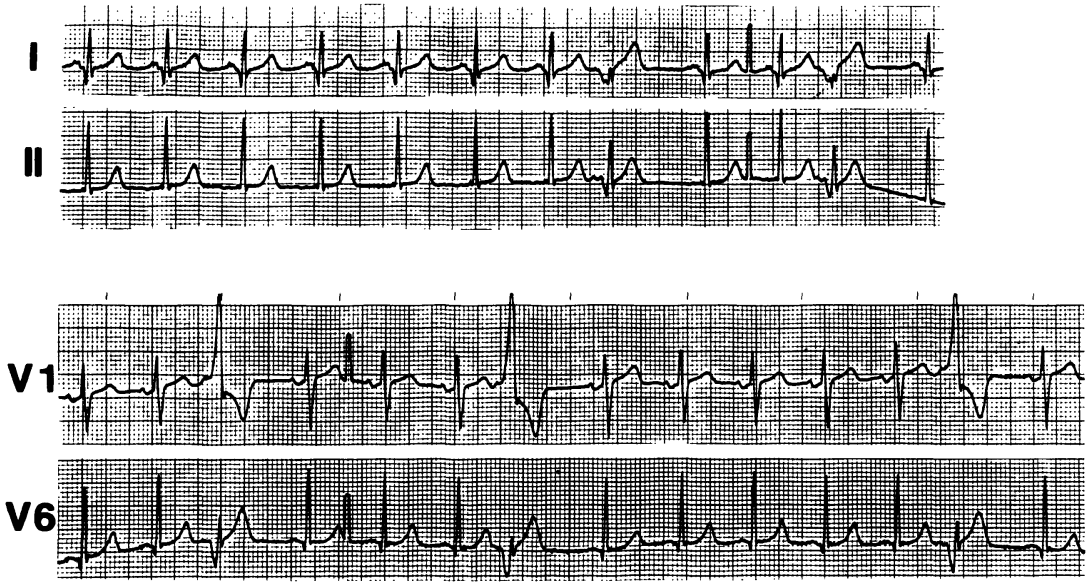

図 4 心房期外収縮が副伝道路を優先的に通って心室の早期興公を生ずるために異常な QRS 波形を呈し，心室期外収縮と誤診されやすい一例 

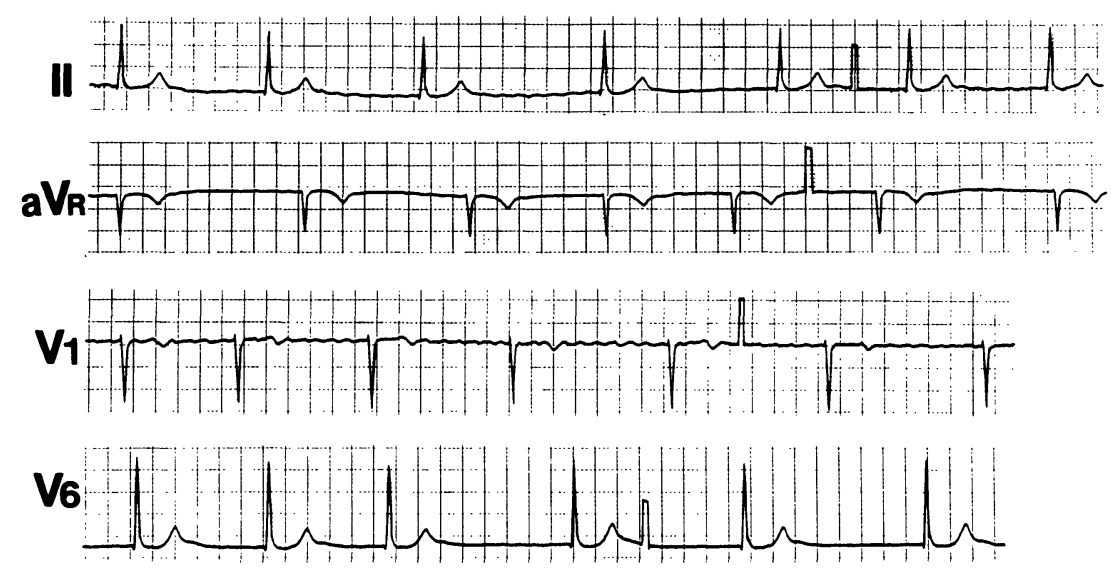

图 5 房室接合部㭪充収縮の頻発を示す心房細動
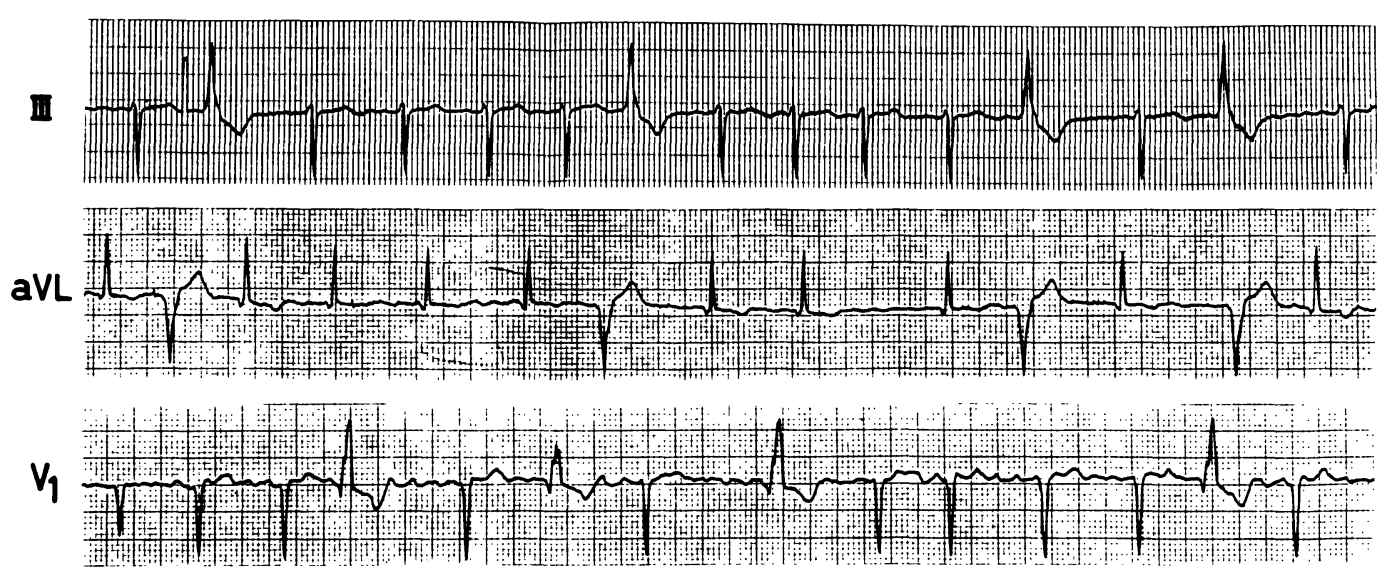

図 6 心室副収縮を伴う心房細亜

広い異常な波形の心室群がかなり頻繁に発生 しているのがわかる。こうした場合には，上 室性興奮波の心室内変行伝導と心室期外収縮 を鑑別しなければならないのは，ょく知られ た事実である。この鑑別にはいくつかの経験 的法則を用いるが，それらの全部を，ここで 詳細に論ずることはできないので，本例では， 一，二の主な診断論理のみを説明してみよう. まず変行伝導は, 先行する心室興奮周期が 長いために心室内伝導系の不応期が延長し, そこに突然短い間隔で上室性の刺激が侵入し てくるときに心室内伝導が障害されて生ずる のがほとんどである. したがって, 心房細動 時には，長い $\mathrm{R}-\mathrm{R}$ 間隔の後で著明に短い $\mathrm{R}-$ $\mathrm{R}$ 間隔が現われ，それが $\mathrm{QRS}$ 群の変形を伴
つた場合に，変行伝導を疑うことになる。そ うした目でみると，この心電図でも，大部分 の異常 QRS は心室周期が先行周期よりも短 縮したところで発生しているが，その短縮の 程度はわずかであるものも少なくない. 特に $\mathrm{V}_{1}$ 誘導の第 8 拍は, 先行周期(第 6 , 第 7 拍 間)よりも明らかに長い $\mathrm{R}-\mathrm{R}$ 間隔の後で現わ れながら，他の異常心拍と全く同じ波形の幅 広いQRS を示す。こうした所見は，心室期外 収縮をかなり強く示唆するものである。また， 心室期外収縮の場合には, その興奮波が逆行 性の不顕伝導を起こし，これによって房室接 合部に不応期が生ずるため, 後続の心房性興 奮波の心室への伝導が妨げられて, 次に現わ れる正常な QRS 群までの間隔が延長する 
(すなわち休止期を伴う)ことが多い.この点， 本心電図で大部分の異常心室群の後, 正常幅 の QRS が出るまでに比較的長い $\mathrm{R}-\mathrm{R}$ 間隔 がみられるのも，心室期外収縮を推測させる。 ただ，いわゆる一源性の心室期外収縮の場 合には,その前にある上室性心拍との間隔 (連 結期)がほぼ一定であることが多いが, 本例で は，それらが著しい変動を示す。そこで心室 副収縮を疑い，期外収縮同士の時間間隔をす べて計測してみると,長い期外収縮間隔(第III 誘導の第 2 拍から第 7 拍までと, 第 7 拍から 第12拍までの間など) は，短い期外収縮間隔 (同じ誘導の第12拍から第14拍までの間など） のほぼ 2 倍に相当することがわかり，副収縮 の診断が支持される.すなわち，ここでは心 室内伝導系の一部に, 約 $1.52 \sim 1.60$ 秒の周期 をもつ自動性細胞群があり，そこで生成され た刺激は，洞性心拍に伴う周辺組織の不応期 にあたらなければ，QRS 群を作ることにな
る.事実, 上の自動周期をあてはめてみると, たとえば第III誘導で副収縮の刺激発生が予測 されながら心室群が生じなかったのは，第 4 拍の QRS 後約 0.12 秒と第 9 拍の $\mathrm{QRS}$ 後 0.20 秒といった時点に相当し，心室組織はま だ不応期にあったことが確実といってよい. こういった副収縮の場合には，その自動性細 胞群の周囲にいわゆる保護ブロックの部位が あって，洞性興奮波の侵入を防ぐため，その 周期が更新されないので，上のように一定の 時間間隔を維持できるわけである。また，洞 調律や補充収縮と異なり，先行する心拍から 長い時間間隔をおかずに QRS 群を作り得る のも，同じ理由による。

\section{IV.おわりに}

以上のいくつかの実例の分析を通じて，不 整脈心電図の解析に用いる診断論理の一端が 理解できるものと思う。 